\title{
THE IMMORTALS OF MELUHA: RELOCATING THE DISTANT LAND
}

\section{FALGUNI P DESAI}

Shri M.R. Desai Arts \& E.E. Laher Kosadia Commerce College, Chikhili, Gujarat, India

\begin{abstract}
While dealing with relocating of people from one place to another, some main issues related to discussion contained in this paper are relocation and migration and assimilation. With reference to Amish Tripathi's novel The Immortals of Meluha the present study attempts to make suggestions that diasporas should be perceived as depending not so much on dislocation but on relocation, connectivity, interrelatedness or on the multifarious aspects of connections and linkages. Study draws that migration should be seen not for given communities, as uprooting or disruption, it is to be seen as expansion and merging of one ethnic or national group with other. It must be seen as a progression where imagined communities, continuously reconstructed and reinvent themselves, their lives and the other community. In the novel it is in the context of this intersection of connectivity and cultural reinvention and reconstruction migration becomes vital dynamics in the reproduction, rejuvenation, transformation and stabilization of the migrated community. This study adopts qualitative approach and analysis of descriptive analysis of theories of migration as well as settlement, stabilization and growth in new landscapes and ecosystems.
\end{abstract}

KEYWORDS: Meluha, Shiva, Relocating, Journey, Migration

Received: Jun 06, 2020; Accepted: Jun 26, 2020; Published: Jul 23, 2020; Paper Id.: IJMPERDJUN2020427

\section{INTRODUCTION}

Of dwindling dusk: I am the perpetual solitary wanderer.

Within me leaping fairs of Tarnetar.

Neither borrower nor a lender: between you and me no barrier,

Best-loved, dearest among dearer our uniter, pious be our prayer.

My ways simple, straight anterior: never foregather or posterior

Of dwindling dusk: I am the perpetual solitary wanderer.

No stern doctrine: Not even dogma: of humanity we humans are torch-bearer,

Does it matter to bright light? Shinning forth earthen or lantern lamp a carrier.

Never displaying to dazzle like chandelier

Of dwindling dusk: I am the perpetual solitary wanderer.

(Modi, 2007.)

This poem by our honourable Prime Minister of India Shri Narendra Modi reflects spectacular expression sketch of a wanderer. His journey blissfully is towards transforming his individual being into divinity. The wanderer is full of delight and mirth. This poem is from collection of poems Blessed Are These Eyes originally written in Gujarati. 
The poem very appropriately builds the cadence of the wandering spirit of human beings, as wanderer proceeds towards his inner journey within, bringing ultimately harmony and transcendence. The poem tunes alike with the wanderings of Shiva in The Immortals of Meluha. Indeed language is inextricably tied to culture. Modi's poetry is technically regional (Gujarati), yet the sphere of language in the above quoted poems is universal and perpetual, overt by the way he utilizes memory, ceremony and spirituality in wandering of human being. This verse revived my spirit, it sparked in my musings as I was meditating for a super start for writing of this paper on The immortals of Meluha in context of migration and wandering.

Since times immemorial humans beings migrate, relocate and wander from one place to another with aim of settling permanently or temporarily in a new place. People often move from one country to another and this movement is at times internal also within the country itself. Human beings migrate either solely or with family, or in groups, clans or tribes. Migration is an inherent natural human tendency, essentially linked with the genesis of human race. Described as 'India's first literary popstar by world-renowned film director Shekhar Kapur, Amish's unique combination of crackling story-telling, religious symbolism and profound philosophies has turned him into an Indian publishing phenomenon, with spiritual guru Deepak Chopra hailing Amish's books as 'archetypal and stirring'.Amish's 6 books till now — The Immortals of Meluha (2010), The Secret of the Nagas (2011) and The Oath of the Vayuputras (2013), which collectively comprise the Shiva Trilogy, and Ram - Scion of Ikshvaku (Book 1 of the Ram Chandra Series) (2015), Sita Warrior of Mithila (Book 2 of the Ram Chandra Series) (2017), and Immortal India - Young Country, Timeless Civilisation (Amish's first non-fiction book) (2017) - have 4 million copies in print with Gross retail sales of Rs. 120 crores. His books have been translated into 19 Indian and International languages. The Shiva Trilogy is the fastest selling book series in Indian publishing history. (Tripathi Amish https://www.authoramish.com/news-n-media-about-author/ last retrived, 2020)

Amish Tripathi's novel The Immortals of Meluha is studied here in perspective of migration to distant lands, consequential of progress of existing tribes. The setting of the fiction is 1900 BC, the era foretelling Indus Valley Civilization at threat. With reference to Meluha the paper projects how journeying, immigrating, relocating and resettling is central to human existence and is as old as human civilization. It reveals how migrating is human tendency for expedition to luring lands. The protagonist of the novel Shiva and his people after going for permanent living in other region away from region of origin of their birth, build harmony in other land. In process of migration, relocation and settlement Shiva and his tribe merge with Meluha. It reveals how and why moving to other land is necessity for economic, social \& political reason for any human race. Similar is the case of Shiva and his people in the novel. The paper traces how migration of Shiva and his people is helping both, the original \& destination tribes. The concluding part of the study reveals how The Immortals of Meluha is depicting a relocation that have assertion of progressivity, peace and harmony.

Meluha is a near ideal realm, established by Lord Ram the ideal ruler. This once self-righteous kingdom of Suryavanshis is in great trouble. Their life line and their elixir greatly worshipped river Saraswati is gradually drying to disappearance. They also face destructive fanatic terrorist attack from the east, the land of the Chandravanshis who have allied with the Nagas, a cursed race with physical deformities. Meluhan King Daksha, sends his representative to North India in Tibet, to invite the tribes to immigrate to Meluha. Gunas is one of the invited immigrant tribe, their chief is Shiva. He proves to be a brave warrior and defender later, after the settlement in new land. Shiva accepts the offer to immigrate and they travel to Meluha. They reach Srinagar after a long journey and are warmly welcomed in Meluha. They are greeted by Ayurvati, the Chief of Medicine of the Meluhans. Shiva and his tribe are overwhelmed with the Meluhan lifestyle. During their first night, the Gunas are high fever stricken and sweating. The Meluhans, under Ayurvati's instructions nurse them to 
wellness. Ayurvati discovers in serendipity the blue necked Shiva. As he is the only one resisting the symptom and that his throat has turned blue. He is proclaimed as Shiva the savior and the eventful story of relocation of tribe begin.

\section{LITERATURE REVIEW}

\section{Theories of Migration}

One aspect of the social grounding of aspiration and desire is that individual attitudes towards migration cannot be agreeably divorced from those that are manifest in the social context. An aspiration to migrate reflects the transformative potential of migration and implies that this imagined transformation is not only viewed positively by the prospective migrant, but is also institutionally embedded. Though analytical vocabularies differ, this observation is well established in analyses of so-called cultures of migration (Jørgen \& Francis, 2018).

In the 1980s and 1990s, the dominant mood in countries of origin shifted from condemnation to celebration of emigrants, and the migrant-as-role-model became an officially authorized driver of migration aspirations. There is an extensive conformity that migration can generate fiscal and other benefits for destination lands. The precise nature and size of these benefits at a given time critically depends on the extent to which the ability of invited immigrants are matching to those of host land. In the novel protagonist migrant Shiva and his tribe are more skilled at war and defence than Meluhans. So they have positive effects for security of the land. This safety brings stability, peace, harmony and prosperity for all.

Shiva and his tribe are invited immigrants and they take a journey to the other land. Human migration has been an evident happening since the beginning of humanity. Various people take the chance to migrate and choose one's place to live as a valuable tool for improving one's standard and quality of life.

An imaginary tale may not be absolute, it may be a netting of myths. But it is like revisiting times gone by with a prospect of promise. In the novel the communion of Shiva's individual and people's collective consciousness is the blend of immigrant and emigrant, unite of science and religion, history and myth, geography and fantasy land, courage and cowardice, humanity and divinity. A realistic presentation of Shiva and his tribe relocating to distant land makes the reading of trilogyThe Immortals of Meluha.

Geographers were the first scholars who observed and explained the phenomenon of migration (Jørgen \& Francis, 2018). They used physical laws as analogies to explain migration. By the early 1940s, the theory of spatial interactions has been elaborated. First, the gravity model, replaced the variables of physical gravity (distance and mass) with countries' population size and the distance between the host and home countries. Second, the entropy model establishes that the relationship, between spatial interactions within regions, maximizes the migration entropy of the entire system of the regions under study (Wilson, 1981 ). The theory of mobility transition explains changes in migration through demographic transition (Zelinsky,1971).

Accordingly, social modernization causes a continuous diversification and an increase in human mobility. A decade later, Wilson presented the catastrophe theory of bifurcation which means a mathematical method of changes in the qualitative or topological structure of a given group. The geographer determines the point where the analyzed dynamic system undergoes quantitative changes in turn associated with slight modifications in some parameters. According to the theories given by geographers, distance, population, social modernization, and environmental disasters are the main causes of human migration. Sociologists have also studied the phenomenon of migration. The concept of intervening opportunities as the main determinant of migration (Stouffer,1960). The idea of the 'push' and 'pull' factors that explain migration. On 
the one hand, pull factors in the destination country included: higher salaries, employment opportunities, security, welfare, etc. On the other hand, push factors in the migrant's' home country encompass: humanitarian crises, military conflicts, environmental disasters, poverty, and unemployment (Jørgen \& Francis, 2018). Migrant networks represent pull factors that impact people who share friendships, kinships, or just the country of origin with migrants (Taylor, 1986). Recently generalized the idea of ethnic networks and developed the theory of transnational spaces, which identifies the different waves of migration as influenced by links between individuals and groups in home and host countries. (Faist,2000). In addition to sociological theories, there are two major socio-economic theories that are found in the literature. The theory of cumulative causality considered migration as an evolutionary process that influence the institutional and socio-economic changes in countries of origin and recipient countries alike. (Massey, 1990).

It is obvious that the overview of few theories as above, despite their fixed area in their corresponding disciplines, use similar way of thinking, concepts, and approaches. The summarized record of history of human migration is given to understand the origins and the evolution of the determinants of migration. This study relates it to merging of Shiva and his Guna tribe with Meluhas, as a first step to create a unifying model. Natural disasters, armed conflicts, and social turmoil are subordinate to the security determinant, for the invited immigrants like Shiva and his Guna tribe.

\section{METHODOLOGY}

This study adopts a qualitative method using descriptive content analysis method. The findings are dependent on the interpretations of literature studied. Descriptive content analysis method is used to study the progressive prospects of migration in Amish Tripathi's fiction The Immortals of Meluha. It is the source of research data. In this study explanatory interpretive analysis of applicable data of migration is done( Jørgen \& Francis, 2018). Paper Prioritizes method of critical thinking and making convincing points on how migration brings progression and positive outcomes (Massey,1990). Migration trend's major characteristics include (i) people who had migrated, it disseminated the idea that becoming a migrant means being a hero( Jørgen \& Francis, 2018). (ii) Migration to another country is one of the most impactful decisions in life as migration breaks the systematic patterns in which people live their lives (Graham and Markowitz, 2011). The validity of research findings are made by theoretical triangulation method, the findings are drawn as the study show that in The Immortals of Meluha migration brings progressivity to both the host and the migrant following three stages in the sequence (i) Transmission, (ii) Stabilization, (iii) Concentration. Finally with the settlement of migrants and emergence of Shiva as hero the struggle of Meluhans with intruders come to an end. Final note is victory and harmony.

\section{DISCUSSIONS}

We humans are born wanderers, we are perpetual wanderers, we wander in imagination, we wander in reality on lands and seas and skies, eventually we settle where necessities are met, ideas transform to realities, life breaths and finds security; and well being comes in a holistic way for individual as well as group. In process of moving from one place to another, humans use to survive on hunting and gathering food and other fundamentals of survival. It is apparent that the first migration was motivated by survival drive. Humans always wanted to settle to find rivers and maneuvers where they can find food, fruits, and plants. we can assume that in the beginning families were the units, the social connections began to evolve forming the tribes. The process of settling and migration is the result of thousands of years of wandering life. Humans shift from one spot to another in search of water and apt weather, the surroundings where they are welcomed. The extension of this progress leads to the dispersal of humans and so to the population of the world. Generally speaking, given these conditions, water and sufficient conditions to survive represent the natural factors responsible of humans' dispersal around the world. 
When humans have already occupied almost the most parts of the planet. The wandering process does not conclude with the dispersion of humans across the planet. The main thing about the stabilization period is that humans, in addition to hunting and gathering, learned how to domesticate animals, and agriculture began to play an important role in their decisions to transfer and relocate. The farming occupation and the protection from invasion of enemies links tribes to their land and consequently slows down wandering migration flows, which marks the end of the diffusion era and the beginning of the period of stabilization starts. Now we are aware of the fact that humans regroup to live in tribes given the importance of security, farming, water and conducive climate for survival. Groups of people who share notions of race and beliefs begin to form groups, clans and cluster, creating bonding between them, their people and specific geographic area. At this stage of the progression, a new form of likely choice and stabilization starts.

Cohesive tribes began to function like individual organisms, competing with other organisms. The tribes that were more cohesive generally won. Natural selection therefore worked on tribes the same way it works on every other organism ( Jørgen \& Francis, 2018). From the above discussion a point can be drawn that, stronger groups like Guna and their group leader like Shiva occupy the most approving position with regard to the main determinants of protecting the people and assuring their security, survival as well as progress.

Counting upon water resources and conducive climate specific constituents of human existence and survival are to be taken in to consideration. Attacks and enemy invasions became the major cause of human relocation; a condition that tinted the role of security as an important constituent of human migration. In reality, like water and climate, the factor of security existed before humans because of natural disaster. Rivalry between tribes create conflict, and then heighten the concern of security as the third major determinant of human migration. The idea of one's homeland is such that it is the very real space from which only certain level of redemption is possible. This reading of the homeland must be placed alongside another truth about migration history while reading The Immortals of Meluha. In the novel under study immigrants do not return to their homeland. Coming of Shiva and his tribe to land of Meluha adds security to the land of Meluhans. Shiva and Guna tribe land from their homeland to Meluha to bring peace, progress and prosperity.

The absorption of population is the outcome of the diffusion and the stabilization migrations, guided mainly by water accessibility and conducive climate, at primary level and strengthened by the inherent need for safety, at secondary level. The inherent need for safely of Meluhans leads to invite Shiva and his tribe to Meuha. The Guna tribe and their leader Shiva are invited to land of Meluha for protection of Meluha against terrorist attacks of the enemies.

Shiva is a man who travels from the distant land of Tibet to Meluha, his fearless, selfless acts makes him Mahadev, from a migrant. Shiva's coming to Meluha is not forced upon him rather it is out of will. Exploration of the pattern of relocation of Shiva and his tribe and their impact on Meluha can be observed while Guna tribe march to Meluha. The flow of Shiva and his tribe have distinct spirit in each gesture, action and relation. An idea about the factors behind relocation shows the skill set of relocated tribe. It is the journey of a man of flesh and blood, Shiva towards becoming divinity Lord Shiva. While we turn the pages of the novel we witness Shiva's journey from being Man of flesh and blood to Mahamrityumjaya. Shiva is recognized as the prophesied destroyer of Evil due to his Neelkanth-the blue throat. Shiva is the chief of Guna tribe. Shiva is altered into Neelkanth and becomes the redeemer of Meluhans.

The name Shiva is euphemistic and is used as an attributive epithet not particularly of Rudra, but of several other Vedic deities. One of the earliest uses of Siva as a proper name of Rudra is found in the Svetasvatara Upanisad, in which beginning of the cult of Rudra-Siva was traced. All the uncanny and baleful traits of Rudra-Siva start from the conception of 
a deity of mountain and forest. Even his wife is the daughter of the mountains. Is there any couple of deified hunters at the back of this concept? The custom of deifying human beings of supernatural powers and worshipping them as gods was very probably non- Vedic and arose with the warrior tribes. The pre-Aryan proto-Siva of the Harappa civilization is an arch yogin with the eyes fixed on the tip of the nose, with feet drawn up beneath him, toes turned down and hands extended above the knees. A non-Aryan mountain deity has definitely lent some of his characteristics to Rudra, the earlier counterpart of Siva, from the very beginning. The relation with hill tribes is indicated by his epithets Girisanta, Girisa, Giritra, etc., as found in the Satarudriya section of the Yajurveda and the Svetasvatara Upanisad these being regular names of Siva in post-Vedic mythology. ( Chakravati, 1986)

The Guna tribe is received with respect, love and regards in Meluha and it is the sign of communion and first step towards harmonious progressivity. The welcome prospect unfolds in following pattern of positivity and progressivity. The entire city of Srinagar was a picture of cleanliness, order and sobriety. Nearly twenty thousand souls called Srinagar their home. Now an additional two hundred immigrants had just arrived from Mount Kailash. And their leader felt a lightness of being he hadn't experienced since that terrible day, many years ago. Shiva thinks he have escaped. He can make a new beginning. He can forget. As Meluha is the land of perfection in terms of technical advancement and physical infrastructure reinstating all time-honored traditions, values and ethics.

The caravan travelled to the immigrant camp outside Srinagar. The camp had been built on a separate platform on the southern side of the city. Nandi led Shiva and his tribe to the Foreigners' Office, which was placed just outside the camp. Nandi requested Shiva to wait outside as he went into the office. He soon returned, accompanied by a young official. The official gave a practiced smile and folded his hands in a formal namaste. He said, welcome to Meluha. He was Chitraangadh. Their orientation executive. He was their single point of contact for all issues whilst they landed in new place.

I believe your leader's name is Shiva. Will he step up please?' Shiva took a step forward. 'I am Shiva.' 'Excellent,' said Chitraangadh. 'Would you be so kind as to follow me to the registration desk please? You will be registered as the caretaker of your tribe. Any communication that concerns them will go through you. Since you are the designated leader, the implementation of all directives within your tribe would be your responsibility' Nandi cut into Chitraangadh's officious speech to tell Shiva, 'Sir, if you will just excuse me, I will go to the immigrant camp quarters and arrange the temporary living arrangements for your tribe.' Shiva noticed that Chitraangadh's ever-beaming face had lost its smile for a fraction of a second as Nandi interrupted his flow. But he recovered quickly and the smile returned to his face once again. Shiva turned and looked at Nandi. 'Of course, you may. You don't need to take my permission, Nandi,' said Shiva. 'But in return, you have to promise me something, my friend.' 'Of course, Sir,' replied Nandi bowing slightly. 'Call me Shiva. Not Sir,' grinned Shiva. 'I am your friend. Not your Chief.' A surprised Nandi looked up, bowed again and said, 'Yes Sir. I mean, yes, Shiva' ( Tripathi, 2012). This is the first sign of their bonding

Shiva turned back to Chitraangadh, whose smile for some reason appeared more genuine now. He said, 'Well Shiva, if you will follow me to the registration desk, we will complete the formalities quickly'. The newly registered tribe reached the residential quarters in the immigration camp, to see Nandi waiting outside the main gates; he led them in. The roads of the camp were just like those of Srinagar. They were laid out in a neat north-south and east-west grid. The carefully paved footpaths contrasted sharply with the dirt tracks in Shiva's own land. He noticed something strange about the road though. 'Nandi, what are those differently coloured stones running through the centre of the road?' asked Shiva. 'They cover the underground drains, Shiva. The drains take all the waste water of the camp out. It ensures that the camp remains clean and 
hygienic' Shiva marveled at the almost obsessively meticulous planning of Meluhans( Tripathi, 2012). Second step where Shiva is establishing acquaintance with Meluha and Meluhans.

Shiva is awake in his bed constantly. He was wearing an orange colored dhoti. The tiger skin had been taken away for cleaning. His cotton angvastram was lying on a low chair by the wall. A half lit chillum lay forlorn on the side-table. This cursed bed is too soft. Impossible to sleep on! Shiva yanked the bed sheet off the mattress, tossed it on the floor and lay down. This was a little better. Sleep was stealthily creeping in on him. But not as strongly as at home. He missed the rough cold floor of his own hut. He missed the shrill winds of Mount Kailash, which broke through the most determined efforts to ignore them. He missed the comforting stench of his tiger skin. No doubt, his current surroundings were excessively comfortable, but they were unfamiliar and alien. As usual, it was his instincts which brought up the truth it was not the room that was uncomfortable it was Shiva's thought of homeland. Here memories bring uneasiness.

Intake of somras makes Shiva's throat blue, Ayurvati an expert renowned doctor notices it and that very moment she pronounces her faith, her faith means faith of the Meluhans. The utterance of Ayurvati is the proclamation of progressivity. it is a declaration which says that theit the invited immigrants brought with them redemption as they are the elixirs of existence. They are the messengers of progressivity.

Shiva change to Neelkanth, the blue necked one due to Somras. Ayurvati was first one to notice the blue throat of Shiva. Ayurvati was speechless when she saw Shiva with blue neck. As Shiva pulled the cloth off, silent room was filled with Ayurvati's scream she staggered back. she covered her mouth in shock. Her knees were too weak to hold her up. She collapsed with her back against the wall, never once taking her eyes off Shiva. Tears broke through her proud eyes. She kept repeating, mantras and she was overwhelmed by the thought that their savior arrived.

Shiva is symbolized both as the god and the vanquisher of death Mahamrityumjaya. Shiva realizes that even in the highly developed civilization like Meluha conviction and belief overpowers everything. Meluha is near ideal empire made by Lord Rama one of the supreme king. However the Suryavanshis faced misfortune as their chief elixir river Saraswati was on soon about to become waterless, it was getting devoid of water, it was gradually drying and they were to die with the drying of the river. They also faced distressing terrorist attacks from the east, the land of Chandravanshis allied with Nagas, a cursed race with physical distortion. The faith of Meluhans was that a person with blue throat the Neelkanth. Who will come as their savior and rescue them from all calamities. The King Daksha therefore solicited Guna tribe to migrate to Meluha. Those invited immigrants the Gunas and their Chief Shiva the heroic warrior and defender is to become the saviors of Meluha.

The Satarudriya section of the Yajurveda alludes to Rudra's blue-neck (Nilagriva). But the linking of the two facts, namely, drinking of poison and blueneck, is post-Vedic. The story is well known to the students of Indian mythology, namely, how Vasuki, the serpent king, at the time of the churning of the milk ocean for ambrosia (amrta), vomited halahala, the deadly poison, which enveloped the world in a destructive conflagration, and how Siva, at the request of the gods, swallowed the poison and kept it in his gullet which turned his throat blue, whereupon he is known as Nilakantha. (Chakravarti, 1986)

The Meluhans announce Shiva as the Neelkanth, their legendary savior. Shiva is drawn to Devagiri, the capital city of Meluha, to see King Daksha. During their stay Shiva and his companions, Nandi and Veerbhadra, meet a beautiful and mystifying maiden, who has an aura and radiance of piousness on her countenance. She is Princess Sati, the daughter of 
Daksha and is a Vikarma an untouchable in this life due to sins of in her previous births. Shiva's energies save the people. The concept of law of Karma is explicit in Meluha. Here the glory of Harappan civilization meets Vedic religion.

Shiva asks about the Nagas. They are reported as cursed people by Nandi. They are born with ugly abnormality because of the sins of their previous births. Deformities like extra hands or horribly misshapen faces etc. Shiva inquires about Vikarma women. Nandi says sadly, Vikarma people, are people who have been punished in this birth for the sins of their previous birth. Hence they have to live this life out with dignity and tolerate their present suffering with grace. This is the only way they can wipe their karma clean of the sins of their previous births. Vikarma men have their own order of penance and women have their own order. people's own karma decide their Vikarma staus. For example if a woman gives birth to a still born child, then it is believed that she is punished as she had committed some terrible sin in her previous birth. Or if a man suddenly contracts an incurable disease and gets paralysed, it is believed that the universe is penalizing him for the sins of his previous life.

During a the puja in a city in honour of Shiva's arrival, a man disrespectfully talks to Shiva for allowing a Vikarma (Sati) to attend the puja. Furious by the disregard shown by the man to Shiva, Sati confront the man for an Agni Pariksha. Even though the chances for Sati's triumph were little, she prevails the Agni Pariksha and instead of assassination of the man, she shows compassion and grants forgiveness to him. On their way to another city, the group comes across a village under attack. As they rush to the save the village, they find out that it is being attacked by the Nagas and some Chandravanshi troops. During the combat, a naga fires fire arrow towards Shiva. But Sati shields Shiva courageously. Severely hurt and wounded, she is taken to the village where Ayurvati medicates her. Sati's life is on risk due to of the poison of the arrows. Somras brings life for Sati.

Shiva discovered the truth of somras when Brahaspati takes Shiva to mount Mandar to the wellknown Somras production place by the waters of the river Saraswati. Shiva learns that the fluid that turned his throat blue was in actually concentrated somras, which can be dangerous in its pure form. Shiva was safe even after drinking strong concentrated somras. This was the sign that, Shiva was the Neelkanth. Shiva discovers the fact that the medicinal values somras blessed the Meluhans with long life. Since that time Brahaspati and Shiva become close friends.

We have reasons to believe that one of the drugs by means of which the Vedic Rudra cured the afflicted and even raised up the dead, was Soma, the elixir of immortality. The Soma plant grew on the slopes of mountains, specially the Munjavat, beyond which Rudra was entreated to depart. We have a hymn in the Rigveda where Soma and Rudra are jointly implored. In the Atharvaveda Rudra and Soma are requested together to drive away the hostile disease. In the Taittirlya Samhita, Rudra is described as the 'lord of the Soma plant'. ( Chakravarti, 1986)

Daksha comes to visit her daughter and requests Shiva to marry his daughter. Shiva tries to court Sati, but she rejects his advances. Eventually Shiva falls in love with her they choose for tie of marriage. Vikarma law forbid their marriage. Infuriated by such customs and law, Shiva declares his identity as Neelkanth and pledges to abolish the Vikarma rule. Daksha agrees to the marriage of Sati to Shiva gladly. Shiva is bent on challenging and changing the established ideology of the nation as he thinks that Vikarma system is completely unfair. He observes that almost one twentieth of the people in Meluha are Vikrama. Shiva is concerned how can they keep so many people as outcast forever. He is determined that system needs to change. 
One fine morning Meluha is filled with thunderous sounds coming from Mount Mandar. Shiva and his men arrive at the hill the see a huge portion of Mandar blasted off and many of the enemies are killed. There is no sign of Brahaspati, but Shiva sees the symbol of the Nagas. They have connection to the deceitful warfare of the Chandravanshis. Enraged Shiva declare war on the Chandravanshis. Consulting Devagiri's Chief Minister, Kanakhala and the Head of Meluhan Army, Parvateshwar, Shiva marches towards Swadweep, the land of the Chandravanshis. There is a fierce warfare between the Meluhans and the Swadweepans. Meluhans victory bring glory. The Chandravanshi king is taken as captive but is furious on seeing the Neelkanth. The Chandravanshi princess Anandmayi disclose that they had myth that the Neelkanth who will be their savior against malevolence Suryavanshis. Shiva is astonished and quite concerned. With Sati he visits the famous Ram temple of Ayodhya the capital of Swadweep. There the priest tells him about karma, fate and his choices in life, which would guide him in future. As Shiva comes out of the temple, he notices Sati standing out of the temple waiting for him and a Naga standing near a tree. The people of Meluha along with Shiva proceed to liberate Sati.

\section{CONCLUSIONS}

Based on the above discussion of simple migration and relocation of Shiva and his tribe the following conclusions are drawn regarding their stabilization and concentration in Meluha:

- Groups of individuals linked by common purpose, or that shares a specific ethnicity and beliefs moved instinctively together to safeguard their security. Meluhans merge with Guna tribe to protect themselves against their opponents Chandravanshi and the Nagas.

- The immigrants Shiva and his tribe were invited by Meluha and were treated with great respect, honor and reverence as most highly regarded guests. Their journey is ascending towards progressivity as their relocating strengthens the Meluhans.

- During Guna tribe's journey towards Meluha they had information about relocation destination. Information about place of relocation was very precise and clear, at the same time it was imaginary as the Gunas never saw the land of Meluha before. They never knew what kind of stability and intransience will be there for them in Meluha.

- Phase of the of relocation of Guna tribe and Shiva evolve them to be more technically organized and responsive people on the other hand the very presence and Shiva strengthen the people and land of Meluha. He ascends as their savior.

- The three's rule suggests that humans cannot survive without water more than three days. The second vital human need is obviously food, which is strongly related to water availability and adequate climate. If the human beings secures these vital expectations, they looks for a safe place to settle down. Once their existence is ensured, humans desire to improve their life by seeking a favorable economic and social environment that depend on the three former determinants. Human migration determinants are therefore the same in the macro and the micro levels, We see this same pattern in episode with Shiva and his tribe.

- An idolization of the recognized dwelling and the individual consciousness of Shiva leads to collective consciousness and commitment. Meluhans believe in the Neelkanth blue throat one will be their savior. They have strong conviction that he will arrive and save them from the evil Chadravanshis. By the end Shiva learns that 
Chadravanshis too believe in the same legend. He brings harmony and comes to terms even with the Naga and the real evil is eradicated.

- A strong cultural collective consciousness sustained over a extensive point in time. Based on a sense of uniqueness, a common history and the faith in a common fate; exists between the Suryavanhis and Chanravanshis.

- Shiva as an immigrant finds out that there is a troubled relationship among host tribes, Suryavanshi and Chandravanshis due to lack of acceptance and there is possibility that another calamity might befall both the tribes. They believe in same redeemer Shiva. The Guna tribe and Shiva have a sense of empathy and solidarity with both tribes and Shiva coverts possibility of a distinctive yet creative and enriching life into reality.He creates harmony in host land of Meluha with a tolerance for pluralism. Gunas prove to be the realization of faith for both Suryavanshis and Chandravanshis.

Narrative of Meluha involves the thought of relocation. The displacement occurs and narratives of journeys are undertaken on account of economic or political compulsions. The The Immortals of Meluha begins with an idea resettling and relocation of tribe to the unknown land.

Shiva is not a inhabitant of Meluha. He is the Tibetan immigrant, the leader of a tribe called Gunas. Nandi, the Meluhan ambassador updated Shiva about the chance availed to the immigrants by their government. Shiva was persuaded and convinced to hear about the security, harmony and affluence which are like far-off imaginings for his tribe. He decided to immigrate to Meluha with his tribe that changed their lives completely. He believe the change was for the better. Anything was better than the pointlessness of the violence they faced daily in their homeland.

Shiva though an outsider raises his voice against the prevailing misleading traditions and religious beliefs of Meluha. He challenges the Vikrama tradition; he questions the Maika system and shudhikaran ceremony. The thoughts of dislocation, estrangement, exile, nostalgia, alienation, longing for the homeland and identity-crisis are almost not related much often with Gunas. on the other hand they merge in accord and add to the strength of Meluhans tribe is evolves with a more organized and contented life.

Thus the present study asserts through their journey the invited immigrants Shiva and his Guna tribe add to the development of the Meluha simultaneously adding to their own stage of evolution and development. The immigrant tribe Gunas and his tribe outline the pattern of simple migration and relocation as shown in the Table-1: 
Table 1

\begin{tabular}{|c|c|c|c|c|}
\hline \multirow{4}{*}{$\begin{array}{l}\text { Simple migration } \\
\text { pattern of Shiva and } \\
\text { his Guna tribe }\end{array}$} & Stages & Episodes & Movement & Impact \\
\hline & Transmission & $\begin{array}{l}\text { Immigration of } \\
\text { Shiva and his tribe } \\
\text { to Meluha on } \\
\text { invitation of the } \\
\text { king Daksha }\end{array}$ & $\begin{array}{l}\text { Shiva and his Guna } \\
\text { tribe are the Invited } \\
\text { immigrants }\end{array}$ & $\begin{array}{l}\text { Resource } \\
\text { availability and } \\
\text { Adequate facilities }\end{array}$ \\
\hline & Stabilization & $\begin{array}{l}\text { They gradually } \\
\text { merge with land and } \\
\text { people of Meluha }\end{array}$ & $\begin{array}{l}\text { Meluhans as Shiva } \\
\text { recognized as the } \\
\text { redeemer of } \\
\text { righteousness of the } \\
\text { race. }\end{array}$ & $\begin{array}{l}\text { Security, Safety and } \\
\text { reformation }\end{array}$ \\
\hline & Concentration & $\begin{array}{l}\text { Shiva settles down } \\
\text { and is recognized as } \\
\text { Neelkanth }\end{array}$ & $\begin{array}{l}\text { Shiva emerges } \\
\text { victorious in war } \\
\text { and makes decision } \\
\text { for the race. vows to } \\
\text { bring reforms and } \\
\text { harmony in tribes. }\end{array}$ & $\begin{array}{l}\text { Equal and governing } \\
\text { prominent status of } \\
\text { Shiva in land, as } \\
\text { immigrant } \\
\text { component of } \\
\text { progressivity }\end{array}$ \\
\hline
\end{tabular}

Similar study of other literary works from world literature can be undertaken it can lead to comparative study and innumerable new horizons and creative interpretations can be made which can add to the global knowledge constratum.

\section{REFERENCES}

1. Chakravarti Mahadev. 1986. The Concept of Rudra Siva Through Ages Motilal Banarasidas, $\quad$ New Delhi, 27-70, 57, 34-35.

2. Faist, T. 2000. The Volume and Dynamics of International Migration and Transnational Social Spaces. Oxford University Press, Oxford, 29-33.

3. Graham C Markowitz J. 2011. 'Aspirations and Happiness of Potential Latin American Immigrants' Journal of Social Research \& Policy, vol. 22, 9-25.

4. Haidt, Jonathan. 2012. The Righteous Mind: Why Good People Are Divided by Politics and Religion, Pantheon Books, New York, 103.

5. Jørgen Carling \& Francis Collins.(2018).Aspiration, desire and drivers of migration, Journal of Ethnic and Migration Studies,44:6,909-926,DOI: $\quad$ 10.1080/1369183X.2017.1384134.

6. Massey, D. S.1990. Social structure, household strategies, and the cumulative causation of migration, Population Index, 56: 3, 6.

7. Modi Narendra. (2007) AANKH AA DHANYA CHEE, Image Publications, Ahmedabad.

8. Stouffer, S. A.1960 Intervening opportunities and competing migrants. Journal of Regional Studies, 2(1), 187-208.

9. Taylor, J. E. 1986. Differential migration, networks, information and risk. In: O. Stark (ed.), Research in Human Capital and Development, Vol. 4: Migration, Human Capital, and Development. JAI Press, Greenwich, CT.

10. Tripathi, Amish. 2012. Immortals of Meluha. New Delhi: Westland Ltd. 12-14, 17-18, 59, 92-93

11. Tripathi Amish. (2020). https://www.authoramish.com/news-n-media-about-author/last retrived 25th April 2020

12. Wilson, A. G. 1981. Catastrophe Theory and Bifurcation. Applications to Urban and Regional Systems, Croom Helm, London, 62-67. 
13. Zelinsky, W. 1971.The hypothesis of the mobility transition. Geographical Review, 61(2), 219-249.

14. Ambri Shukla, Suman Swati, and Shuchi Srivastava. "The Immortals of Meluha and the Science in their Belief." Impact : International Journal of Research in Humanities, Arts and Literature(IMPACT : IJRHAL) (2014): 89-94

15. Kumari, S. A. N. G. I. T. A. "Rural-urban migration in India: determinants and factors." International Journal of Humanities and Social Sciences 3.2 (2014): 161-180.

16. Bharvad, Rajesh. "The Inheritance of Loss: A Story of Colonized Minds and the Subsequent Impacts of Immigration and Westernization." International Journal of Linguistics and Literature( IJLL) (2014): 25-30

17. Farooq, Muhammad, Khizar Hyat Qamer, and Jaffar Hussain. "Migration and Development: Regional Perspective of Migration in Pakistan." International Journal of Environment, Ecology, Family and Urban Studies (IJEEFUS) 2.3 (2012): 112-120.

18. Singh, Niraj K., and Brijesh P. Singh. "Study of Distance Associated with Marriage Migration." International Journal of Mathematics and Computer Applications Research (2015): 111-116

19. Majhi, Mm, Et Al. "Impacts of Goat rearing in Curbing Distress Migration." International Journal of Agricultural Science and Research (2017): 147-154 